\title{
Leveraging on Mobile Money Business Models for Digital Financial Inclusion of Small Holder Households in Nigeria
}

\author{
Ugwuja V.Cand, Dickson P.M
}

\begin{abstract}
The launch and growth of digital financial services has led to an unprecedented increase in the number of people enjoying access to formal financial services in Africa. Mobile money solutions and agent banking now offer affordable, instant, and reliable transactions in rural villages and urban neighbourhoods where no bank had ever established a branch. This is revolutionary, but Nigeria though having many mobile money operators are more financially excluded than other countries in Africa. Financial exclusion rate in Nigeria is $37 \%$. This is as a result of concentrating only in urban areas and neglecting the smallholder households in the rural communities. This paper examined different mobile money business models such as M-Pesa, Tigo cash and Mobicash that other African countries have used to penetrate their rural communities which made them to be more financially included. Nigeria should then leverage on these models to achieve the same results.
\end{abstract}

Index Terms - Mobile Money, Digital Financial Inclusion, Agent banking, Business Models

\section{INTRODUCTION}

The term financial inclusion came into limelight in the early 2000s and is aimed at ensuring all adults of the society having easy access to a broad range of financial products designed according to their needs provided at affordable cost. These products involve savings, credits payment, insurance and pension. For more economic development in the rural area, improving farmers access and usage of financing is extremely essential. Thus financial inclusion is essential for agricultural growth, economic growth and development. Financial inclusion is a necessary tool that enable farmers to have more sustainable livelihood.

Nigeria currently operates a dual financial system, with the formal and informal sectors operating side by side with little or no interactions (Adeola\& Evans, 2017). Financial inclusion is an essential policy tool used by the government and policy makers to stimulate economic growth, it offers a platform for both low and high income earners to be integrated into the formal financial system for inclusive growth. Financial inclusion has been recognized by policy makers as veritable tool for the attainment of sustainable economic growth and development, and that countries with

Dr Ugwuja Vivian Chinelo, Department of Agricultural Economics and Extension, University of Port Harcourt, Nigeria

Dickson Prudence. M, Department of Agricultural Economics and Extension, University of Port Harcourt, Nigeria. high financial inclusion index tends to achieve high level of economic growth and development. As more people become financially included in the economic system, there is a high level of investment in real or productive activities leading to higher level of output and income (Martine, 2011). Furthermore, financial inclusion helps in reducing the prevalence of informal financial institutions that are in most cases exploitative, it enhances efficient allocation of productive resources and in the process enhances efficiency and welfare by providing avenues for secure and safe financial practices (Chakrabarty, 2010).Over 60\% of the Nigerian adult population are now financially included, but financially excluded proportion of the adult population still remains large (EFINA,2018a).

So many countries in Africa are more financially included than Nigeria. The spectacular expansion of financial inclusion in Sub-Saharan Africa over the past ten years would not have been possible if financial services providers didn't find a compelling opportunity in broadening the reach of their services. For the industry, the important question is whether there is a business model for financial inclusion? The answer is Yes. (International Finance Corporation, 2018). This paper examined different business models for financial inclusion in other countries, which has brought financial exclusion rate to minimum in these countries.

\section{FINANCIAL ACCESS STRAND INSELECTED AFRICAN COUNTRIES}

Nigeria has a fairly large banked population (39.7\%), but also has a high proportion of financially excluded adults at $37 \%$. Amidst a growing population, the challenge is that the high volume of financially excluded Nigerians has not abated despite regulatory interventions such as rural banking to alleviate poverty in rural areas and the establishment of community banks that transitioned to microfinance banks (MFBs). These institutions were not only set up to create store of value for underserved customers, but also to provide line of credit to grow their businesses. Their inability to deliver further widened the inequality gap and worsened the challenge of financial exclusion. Subsequent regulatory interventions since 2011 have embraced the reach and ubiquity of mobile telephony and telecommunications services in support of digital financial services (DFS),(Lagos Business School, 2016). The financial access strand shown in Fig.1 revealed that Nigeria is one of the countries with high financial exclusion rate, ranking second in financial exclusion rate. South Africa has the highest banked 
population of $80 \%$ followed by Namibia (68\%). Fig. 1 also showed that countries like Tanzania, Cameroon, Uganda,
Rwanda and Kenya are excelling in other formal non -banking services such as Mobile money.

\section{FINANCIAL ACCESS STRAND IN SELECTED AFRICAN COUNTRIES}

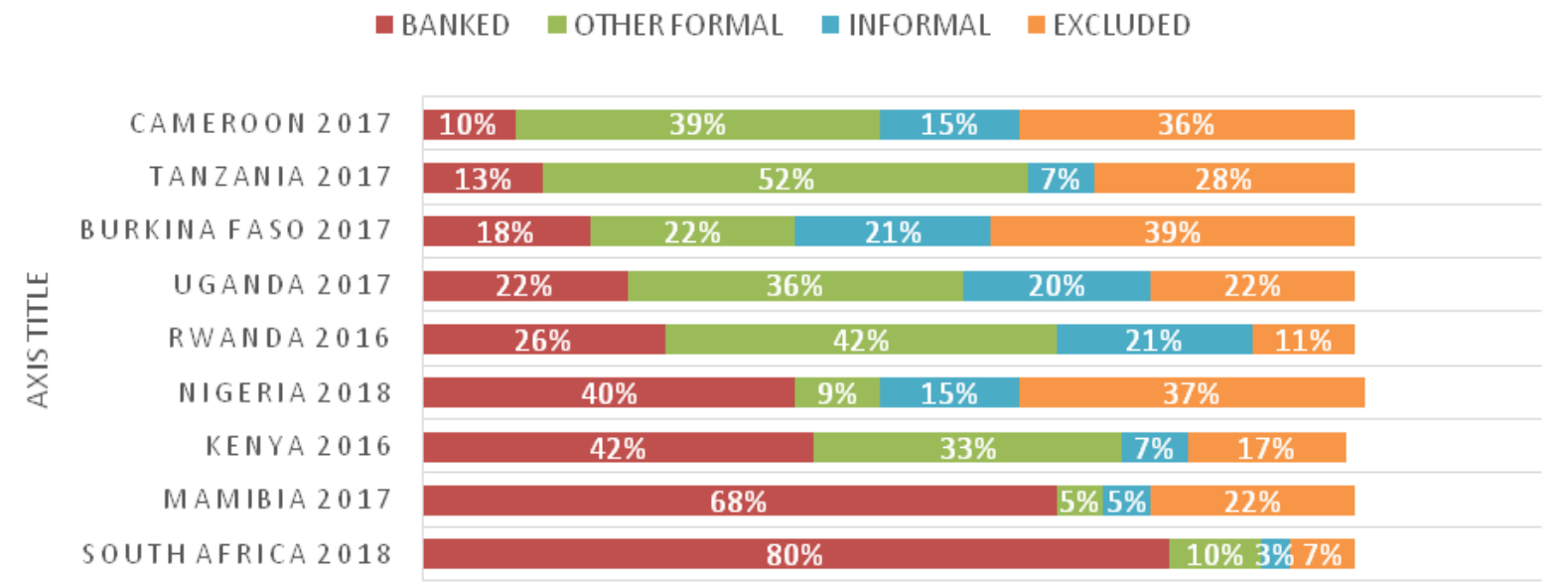

FIG 1: FINANCIAL ACCESS STRAND SELECTED IN AFRICAN COUNTRIES, SOURCE:(EFINA, 2018A).

\section{BUSINESS MODELS FOR DIGITAL FINANCIAL INCLUSION IN OTHER COUNTRIES}

\section{M-PESA: for Money, PESA for Swahili}

M-Pesa is a mobile phone based money transfer, financing and micro financing services launched in 2007 by Vodafone forSafaricomin Kenya. It allows users to deposit, withdraw, transfer and pay bills, purchase airtime, pay money into an account stored on their cell phones. To send balances using pin secured SMS, text messages to other users, including sellers of goods and services. M-Pesa is a branchless banking services that enables customers to deposit and withdraw money from a network of Agents including airtime resellers and retail outlets acting as banking agent. These agents register customers to enable them use this service. As at 2007 M-pesa announced a subscription base of 900,000 users and 1,200 agents operating nationwide with a transaction value of \$71million, and in 2008, 66 percent of Kenyans has used it and which increased users to 4 million people. (Omwansa 2009).M-Pesa has spread and has become the most successful mobile phone based financial service in the developing world.As at the end of the 2017 financial year, M-Pesa had 19 million active users and had generated annual revenues of US\$548 million(Morton,2018).

M-Pesa originated in Kenya spread to Tanzania by Vadocom and other countries like South Africa, India, the service has giving millions of people access to financial system and reducing crime in largely cash based society. M-Pesa developed a branched called M-Shwari which was officially launched in 2012 and drew 70,000 subscribers on day one of its operational launch. It is a combined savings and accessing loan (loan products) launched through a collaboration between the Central Bank of Africa (CBA) and
Safaricom. The only way to deposit or withdraw is through M-Pesa wallet. It aims to deepen and diversify the consumption and income benefits of M-Pesa by offering credit beyond a user's network of family and friends.

To request a loan the customer accesses the M-Pesa menu, select M-Shwari, select request loan enter the amount and enter her M-Pesa pin. If appropriate the customer receives the fund directly into her M-Pesa court. (Communication Commission of Kenya (CCK), (2012).

\section{Mobicash}

Mobicash is a mobile service design to compliment lifestyle by making payment or transfer quick and easy without compromising your security, mobicash is not tied to one bank, it is a platform committed to bringing innovation, convenience and easy access to banking and payment services to everyone, these include those that are not served by financial institution regardless to their financial situation, thus deepening the financial sector.MobiCash works on all phone models and on all network operators. All phones can make payments using MobiCash no matter what phone model or network operator. Model changes, software downloads and changes to phone settings are completely unnecessary. As long as a phone can make a call, you instantly have access to the many advantages of MobiCash (Mobicash,2017). The different ways you can use an MobiCash account include using a phone, a finger print, aMobiCash Card, online access, or using a Merchant or Agent outlet.Mobicash has offered a robust and dynamic mobile banking platform in 19 African country which include Rwanda, Zambia, Zimbabwe, Botswana, Uganda, Burundi, Kenya, Ghana, Tanzania, Cameroon, South Africa, Jordan, Malawi etc.(Mobicash,2017) This platform is engineered and developed to support and sustain the various economic elements that play a role in the supply chain delivery within the key sectors such as agriculture, education, construction etc, (World Economic Forum, 2016). Mobicash account has 
been developed so that all people will be able to conveniently use this account, making it a truly universal product, payments and transfer can be made with finger print, mobicash cards, voice biometrics and phones. Finger biometric is a biometric payment technology that eliminates the need for of carrying around cash, checks or credit cash and removes the risk associated with identity theft, cash theft, loss of credit cards, loss of cash and loss or forgotten pin. Account holder confirms transaction by simply placing their finger on a scanner which records the unique aspects of the fingertips and verifies that their identity is correct. Voice biometric is a payment technology that enables people to transact with their voices in order to reduce the risk such as loss of credit card and forgotten pin. The cost of implementation is low because there is no special hardware required, a simple telephone is all that a user needs to give authority using her voice.

\section{Tigo Cash}

This is a mobile transfer for emerging markets that provide banking and remittance, an innovative telecommunication company that covers a wide range of products portfolio in voice, SMS, high internet access and mobile financial services.It is owned by Millicom,an international telecommunications and mediacompany. It has innovations like East Africa's first cross border mobile money transfer with currency conversion. On the other hand, the TIGO $3 \mathrm{G}$ network gives the best services to its subscribers all over the nation. It enables world remit which is an online service that let people send money to family and friends that resides abroad. Tigo generated $\$ 1,870$ million in Central America, $\$ 170$ million in South America and \$905 million in Africa as at 2010 (Millicom, 2010).

Tigo customers use world remit at any point in time, at their localities and on their cell phones or computers and tigo agents. It can be used for depositing cash, withdrawal of money, mobile money and mobile airtime top up. It involves the use of e-wallet and promotes merchant payment as the functionality. TIGO cash is been used in Ghana, Senegal, Tanzania, Congo, Latin America etc.

\section{CHALLENGES OF DIGITAL FINANCIAL INCLUSION IN NIGERIA}

Low literacy level: Financial inclusions among small holder households have been faced with several issues such as low literacy level and poverty. Most people in rural areas find it difficult to understand the implication and necessary steps to take to ensure or secure access to finance.

Lack of infrastructure: Most rural areas lack the necessary infrastructure (electricity, good road, etc.) that support investment that attracts finance to these areas.

Financial institution: Most financial institutions are not ready to give farmers access to finance (loan) owing to the fact that they see agriculture as a high risk venture.

Unstable network: Unstable networks and poor connectivity are some of the greatest challenges in the agency business in Nigeria. USSD users are the most affected due to unstable platforms and networks. In some cases, network downtimes occur almost daily and agents cope by conducting offline transactions (where agents collect cash from customers and conduct the transactions later during system uptime. It is a risky practice that can be abused by dishonest agents. This can also erode trust and demotivate agents leading to increased churn rates.

\section{WAY FORWARD}

It is critical to consider the right technology choices in the deployment of digital financial service (DFS). Institutional organizational structures, as much as a sound business strategy is the ultimate determinant of the DFS deployment, technology plays a major role in delivering functionality based on the DFS strategy. Financial service provider technology choices should consider the customer value proposition, the intended product mix requirement, and how the services will be delivered including establishment of visionary partnerships. The following are way forward for mobile money penetration in rural communities in Nigeria.

\section{A. A WELL-FUNCTIONING AGENT NETWORK}

All the mobile money agents studied use agent banking, Agent Networks continue to be crucial assets for Digital Financial Service (DFS) providers and have been key to the growth of the industry over the last decade. As of December 2017, there were over 2.9 million agents and 690 million registered customer accounts worldwide. The industry now processes a billion dollars in transactions a day, and in 2017 , direct revenues of over USD 2.4 billion were generated largely from agents performing cash-in and cash-out (CICO) transactions (EFINA,2018b). This will help to overcome the issue of lack of infrastructure because agent banking requires just having an outlet for business. Even though Agent Banking Guidelines were released in 2013 in Nigeria, there has been low uptake despite the huge market potential. It is tethered only in the urban areas, neglecting the rural areas. Critical success factors for both the sprouting and maturity of agent distribution networks include the agent network structures, agent network operational efficiency, agent business viability, liquidity management structures, quality of customer service and agent network control and compliance activities. The health of an agent network determines the viability of a DFS service. A well-functioning agent network, guided by clearly defined processes and standards, can be the difference between success or failure. An efficient network is the best way to address some of the common challenges of struggling DFS services, such as low activity levels or liquidity constraints.

Building a good agent network is hard work. It takes time and it doesn't come cheap. It is a long-term investment, and there are three keys to getting it right: They are;

- Sourcing quality agents: Good agents are hard to find. If you find them, they are not yours to keep. Most markets have legislated against proprietary agents so any investment you make in them makes them more attractive to the competition. All the same, you need top quality agents and should never use sub-standard hiring criteria or bend your criteria.

- Good network management: Agents need constant guidance and supervision. If you make it a box-ticking exercise or outsource or abandon management altogether, agents will reciprocate by diverting their funds, providing 
poor customer services or even committing fraud.

- Incentivize your agents: Any agent will tell you that higher commissions will get them working

harder. When price competitiveness will not allow higher commissions, there are many other ways to make agents happy: training and certification, awards and recognition, branding, etc. Agents are an invaluable part of the DFS ecosystem. A good agent will educate and onboard users, deliver a good customer experience, ensure there are no liquidity issues, act as brand ambassador and engage the market, and harness market intelligence and insight (International Finance Corporation, 2018)

The issue of illiteracy will also be solved because most agents are locals who speak the same language with the rural people.

\section{B. USE OF STRONG INTERNET CONNECTIVITY}

The issue of poor internet connectivity can be solved through the use of Nano-satellites to deliver internet access to rural communities.Existing mobile networks and WiFi often fall short outside urban areas and wealthier countries, whilst traditional satellites that provide wider coverage are expensive and power hungry. Nanosatellites have laid the foundations for developing the Internet of Things (IoT) on a global scale, connecting areas of the world without land communication cover via infrastructures in space. For the business models studied, governments in these countries provided an enabling environment by investing so much on internet infrastructure.

\section{USE OF SECURED FACILITIES FOR SAFER TRANSACTIONS}

Online transactions are usually associated with Cyber-attacks,Cyber threats are becoming more sophisticated with the blending of once distinct types of attack into more damaging forms. Increased variety and volume of attacks are inevitable given the desire of financially and criminally-motivated actors to obtain personal and confidential information. The business models studied have secured facilities for safer banking. MobiCash uses a mix of authentication methods that guarantee increased user functionality and enhanced security while accessing the user account. It uses voice and Fingerprint Biometric technology and the use of passwords or PINs to verify the identity of a person.

\section{USE OF TELECOMMUNICATION COMPANIES (TELCOS) LED MOBILE MONEY MODEL}

Most Mobile Money operators in Nigeria are bank led instead of telcos led, mobile phone companies have exceedingly wide distribution networks. In Nigeria for instance so vast are the distribution networks of the mobile phone companies that you could literally get airtime anywhere in urban and rural areas. Banks, on the contrary, have much fewer distribution outlets such as branches and e-branches/ATMs. Little wonder, therefore, that in deliberately providing a regulatory framework that is led by mobile phone companies rather than banks, Kenya has long provided the biggest success story on the mobile money universe with the successes recorded by its iconic M-Pesa product.

The bank-led mobile money model wherein the deposit money banks play the lead role as is the case in Nigeria and a few other countries, has not made much headway in driving mobile money adoption across the continent, certainly nowhere as near the sort of results that the telco-led model has generated for financial inclusion.

For a country of close to 200 million people with a predominantly youthful population segment, the potential of mobile money to drive financial inclusion is massive. But Nigeria's regulatory authorities need to come to terms with the fact that the bank-led model is not suited to deliver the kind of results we need. The CBN and the deposit money banks need to come to terms with this paradigm. Mobile money may be a financial product but it is inherently a fast moving consumer good, which banks are ill-equipped to market and promote. Nigeria's financial inclusion needs will be best met when the country adopts a telco-led mobile money regime.

\section{CONCLUSION}

The launch and growth of digital financial services has led to an unprecedented increase in the number of people enjoying access to formal financial services in Africa. Mobile money solutions and agent banking now offer affordable, instant, and reliable transactions in rural villages and urban neighborhoods where no bank had ever established a branch. This is revolutionary, but Nigeria though having many mobile money operators are more financially excluded than other countries in Africa. This is as a result of concentrating only in urban areas and neglecting the smallholder households in the rural communities. Other African countries have used different mobile money business models to penetrate their rural communities, Nigeria should then leverage on these models to achieve the same results.

\section{REFERENCES}

[1] Adeola, O. \& Evans O. (2017). The Impact of micro finance on financial inclusion in Nigeria. The Journal of Developing Areas.51(4), 193-206.

[2] Chakrabarty, K. C. (2010). Inclusive growth role of financial sector. Paper presented at the national finance conclave bhubanesswar Orissa India $27^{\text {th }}$ November.

[3] Communication Commission of Kenya (CCK), (2012). Annual Report 2012, Kenya.

[4] EFINA (2018a). EFINA Access to financial services in Nigeria 2018 survey. Retrievable from http://www.efina.org.ng/media-centre/news.

[5] EFINA (2018b). Factors and Trends impacting the Building and Scaling of Agent Networks in Nigeria. Retrievable from http://www.efina.org.ng/media-centre/news.

International Finance Corporations (2018). Digital Access: The Future of Financial Inclusion in Africa. Retrievable at https://www.ifc.org/wps/wcm/...africa/.../201805_report_digital-acces $\underline{\text { s-africa }}$

[7] Lagos Business School (2016). Digital Financial Inclusion in Nigeria: State of the Market Report 2016, Accessible at http://sustainabledfs.lbs.edu.ng/publication.php

[8] Martine, M. (2011). The political economy of increased financial access. Master thesis submitted to Georgetown university, USA.

[9] Millicom (2010). Annual Report and Accounts 2010, Accessible at https://www.millicom.com/media/1484/millicom_annual_report_2010 .pdf 
[10] Mobicash (2017).Cashless Ecosystem for Everybody. Retrieved from https://www.mobicash online.com.

[11] Morton A. ( 2018, August 27). Why Mobile Money has failed in Nigeria. Retrievable at www.thisdayonline.com

[12] Omwansa.T.(2009) M-PESA: Progress and Prospects: Innovations Case Discussion: M-PESA /Mobile World Congress, pp. 107-123.

[13] World Economic Forum. (2016). Ground breaking mobile payment ecosystem to boost financial inclusion in South Africa Retrievable at www.mobicash online.com 